\title{
EFFECT OF PLANT DENSITY ON GROWTH AND YIELD OF TWO SUNFLOWER VARIETIES \\ AbdEI-Ghany, H.M. ${ }^{1}$; M.E. Ibrahim ${ }^{2}$ and Manal F. Mohamed ${ }^{1}$ \\ 1 Field Corps Research Department, National Research Centre, Giza, Egypt. \\ ${ }^{2}$ Agronomy Department, Faculty of Agriculture, Minufiya Univ., Egypt.
}

\begin{abstract}
This work carried out during 2006 and 2007 summer seasons at the Experimental Farm, Faculty of Agriculture, Minufiya University in a spilt plot arrangement with three replications. To investigate the effect of some different types of plant density treatments i.e., 17000,35000 and 70000 plants per faddan, with different space of culture, on growth, yield and its components and quality characteristics of two sunflower (Helianthus annuus, L.) varieties i.e., Vitoflower and Earoflower, which grown under two different plant spacing and number of plant per hill.

The application of the various tested plant density treatments caused significant differences in all studied traits except most of flowering date and oil percentage. The treatment of 17500 plants per feddan when sown in $60 \times 40 \mathrm{~cm}$ with one plant per hill gave the highest values for the most vegetative growth, yield and its components as well as oil yield.

Variety Vitoflower was better than cv. Earoflower in all studied characters $i$. e. vegetative growth, seed yield per plant and oil percentage; on the opposite the variety Earoflower gave the highest values of head diameter and 100-seed weight traits which lead to increase seed and oil yields per feddan.

The maximum sunflower seed production with good quality was obtained by the application of the interaction between plant density 17500 plants per feddan (when sown in $60 \times 40 \mathrm{~cm}$ space of culture with one plant per hill) and variety Earoflower.

It can be concluded from this study that, the optimum plant population for the achievement of maximum yield of sunflower under the conditions of this study lies between 17500 plants per feddan with $60 \times 40 \mathrm{~cm}$ space of culture and 3500 plants per feddan with $60 \times 20 \mathrm{~cm}$ space of culture and single plant per hill.

Keywords: Plant density, Sunflower, growth, yield and quality.
\end{abstract}

\section{INTRODUCTION}

The oil crops included sunflower (Helianthus annuus, L.) did not produce magnificent amount of oils and is not sufficient to cover the local food consumption in Egypt. One of the most important oil crops not only in Egypt but also in the world is sunflower due to its wide range adaptability and widely scattered geographical area (Beard and Geng, 1982), which can grows in both cultivated and new reclaimed soils. In addition, the percent of oil seed content is up to $45 \%$. Moreover, sunflower is one of the four most important annual cops in the world grown for edible oil (Putt, 1977). Therefore efforts have been made for increasing the production of this crop.

Based on the results from different authors, distribution of plants in unit area considered one of the important factors for the achievement of optimum sunflower production and influenced by several factors such as soil fertility and varieties. These findings can be finding in many of literatures 
(Villalobos et al., 1994; Andrad, 1995; Diepenbrock et al., 2001 and José et al., 2004). Many reports indicated that plant density is an effective factor for growth characters i.e. plant height, dry matter accumulation, head diameter, number and seed weight/head, 100-seed weight, seed yield and oil yield. Moreover, it was concluded that increasing number of plant per unit area increased grain and oil yields, while it was concluded that oil content was not affected by plant density. Numerous studies have emphasized the effect of plant density on growth, yield and oil yields of sunflower (Kabelma, 1995; Allam and Galal, 1996; Tanzi et al., 1997; Ortegon and Diaz, 1999 and Naderi, 2000).

The aims of this study were (i) Evaluate the two new used sunflower varieties under some of plant density rates and its effect on growth, yield, yield components and oil seed content, (ii) Measure changes in plant growth and yield due to variation in plant distribution in unit area (iii) Identifying the optimum plant density to obtain the maximum sunflower yield.

\section{MATERIALS AND METHODS}

Two field experiments were carried out at the Experimental Farm, Faculty of Agriculture, Minufiya University during 2006 and 2007 seasons, to study the effect of some plant density treatments on the growth, yield and its components as well as oil seed percentage of two sunflower varieties (Helianthus annuus,L.) namely cvs. Vitoflower and Earoflower.The experimental design was a spilt-plot with three replications. Each experiment included eight treatments which were the combinations between two factors; i.e., four treatments of number of plants per feddan (plant density) were assigned in the main plots and sunflower varieties i.e., the two varieties were occupied in the sub-plots.

\section{A. Plant density}

Numbers of plants of sunflower varieties were distributed on the unit area as follows:

\begin{tabular}{cccc}
\hline Treatments & $\begin{array}{c}\text { No. of } \\
\text { plants/hill }\end{array}$ & $\begin{array}{c}\text { Space of culture } \\
(\mathbf{c m})\end{array}$ & $\begin{array}{c}\text { No. of } \\
\text { plants/fed }\end{array}$ \\
\hline D1 & 1 & $60 \times 40$ & 17500 \\
D2 & 1 & $60 \times 20$ & 35000 \\
D3 & 2 & $60 \times 40$ & 35000 \\
D4 & 2 & $60 \times 20$ & 70000 \\
\hline
\end{tabular}

\section{B.Varieties:}

Sunflower varieties were; Vitoflower (V1) and Earoflower (V2). Seeds were obtained from Field Crops Research Department, Agriculture Research Centre, Ministry of Agriculture, Egypt.

The preceding crop was clover (Trifolium alexandrenum, L.) in both seasons. The soil of the experiment was clay loam texture. Experimental soil ploughed twice, ridged and divided into four equal parts (main plots). The main plots assigned to the four plant density treatments. Each main plot 
divided in two sub-plots, which occupied by the two tested varieties. Total plot size was $12.6 \mathrm{~m}^{2}$ consisted of six ridges each 3.5 meters long and $60 \mathrm{~cm}$ width. Hill spacing was 20 and $40 \mathrm{~cm}$ apart; according to the treatment type, 3-4 seeds in each hill. Seeds were sown using the dry method of planting on $12^{\text {th }}$ and $11^{\text {th }}$ of May 2006 and 2007 seasons, respectively. Thinning conducted after 21 days from sowing to secure one or two plants per hill according to the used treatment. The recommended cultural practices of growing sunflower were properly practiced for the management of the experimental plots, throughout the cropping season. According to the chemical fertilization treatments; the phosphorus was added at the rate of 100 $\mathrm{kg} / \mathrm{fed}$ as a calcium super-phosphate $\left(15.5 \% \mathrm{P}_{2} \mathrm{O}_{5}\right), 50 \mathrm{~kg} / \mathrm{fed}$ potassium sulfate $\left(48 \% \mathrm{~K}_{2} \mathrm{O}\right)$ was applied prior to sowing, and nitrogen fertilizer was added as ammonium nitrate $(33.5 \% \mathrm{~N})$ by the application of $75 \mathrm{~kg} \mathrm{~N} / \mathrm{fed}$ which was added in three unequal doses ; the first one as 15 units at 21 days from sowing, the second one 30 units at 30 days from sowing and the last one 30 units at 40 days from sowing for both tested varieties (Ibrahim et al., 2006).

\section{Studied characters}

The number of days from planting to flowering had been taken. Ten guarded plants were randomly taken from each sub-plot at 90 days from planting to determine the following growth characters:
1. Plant height $(\mathrm{cm})$.
2. Leaf area/plant $\left(\mathrm{cm}^{2}\right)$.
3. Leaves dray weight/plant $(\mathrm{g})$.
4. Stem dray weight/plant $(\mathrm{g})$.
5. Head dray weight/plant (g).

At harvest, ten plants were chosen randomly from the inner ridges to measure yield attributes. While the last inner three ridges from each sub-plot were collected to determine seed yield/fed and oil seed percentage $\%$ as mentioned by A.O.A.C. (1984). The following data were recorded:
1. Head diameter $(\mathrm{cm})$.
2. Seed yield/plant $(g)$.
3. 100 -seed weight $(\mathrm{g})$.
4. Seed yield $(\mathrm{kg} / \mathrm{fed})$.
5. Oil \%.
6. Oil yield $(\mathrm{kg} / \mathrm{fed})$.

Data of both seasons were subjected to the proper analysis of variance (ANOVA) and differences between means were tested for significant against LSD values according to Snedecor and Cochran (1980).

\section{RESULTS AND DISCUSSION}

\section{1- Plant density}

\section{1- Effect of plant density on growth and flowering date.}

The presented data in Table 1 show the effect of plant density on flowering date and some vegetative growth characters for the two used sunflower varieties. Data indicated that increasing number of plants in unit area from 17500 to 70000 plants/fed caused a significant increase in plant 
height trait, while caused a significant decrease in leaf area, leaves dry weight/plant, stem dry weight, head dry weight per plant during 2006 and 2007 growing seasons and its combined, in addition to flowering date in the second season only. While there was no significant effect for plant density on flowering date in the first season and combined data. These results prove the importance of the number of plants in unit area for sunflower and its vegetative growth characters. Through the combined data, the best treatment of plant density was 17500 Plants/fed when sown in $60 \times 40 \mathrm{~cm}$ with one plant per hill (D1), which gave the highest score for all studied flowering and vegetative growth characters except plant height which had the highest score with 70000 plants/fed by space of culture $60 \times 20 \mathrm{~cm}$ and two plants per hill (D4), that is my be due to the competition of two plants per hill and the shortage of space between hills. This point investigated before by Tenebe et al. (1996), Sarmah et al. (2000) and José et al. (2004).

Table 1: Effect of plant density on flowering and some vegetative growth characters of sunflower during 2006 and 2007 seasons and its combined.

\begin{tabular}{|c|c|c|c|c|c|c|c|c|c|}
\hline \multirow{2}{*}{$\begin{array}{l}\text { Characters } \\
\text { Treatments }\end{array}$} & \multicolumn{3}{|c|}{ Flowering date (days) } & \multicolumn{3}{|c|}{$\begin{array}{c}\text { Plant height } \\
\text { (cm) }\end{array}$} & \multicolumn{3}{|c|}{$\begin{array}{l}\text { Leaf area/plant } \\
\left(\mathrm{cm}^{2}\right)\end{array}$} \\
\hline & 2005 & 2006 & Con & 2005 & 2006 & Comb & 2005 & 2006 & Comb \\
\hline $\mathrm{D} 1$ & 58.59 & 5 & 5 & 2 & 9 & I & 1 & 802 & 788.23 \\
\hline D2 & 57.00 & 55.00 & 56.00 & 183.88 & 182.38 & 18 & 714.35 & 740.39 & 727.37 \\
\hline D3 & 55.27 & 53.27 & 54.27 & 189.02 & 187.80 & 188 & 575.92 & 595.50 & 585.72 \\
\hline D4 & 55.21 & 54.32 & 54.77 & 193.40 & 191.33 & 192.37 & 391.49 & 405.41 & 398.45 \\
\hline F. Test & Ns & 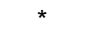 & Ns & & & & & & \\
\hline LSD $5 \%$ & -- & 1.47 & -- & 3.07 & 2.94 & 3.00 & 180.70 & 173.31 & 177.00 \\
\hline
\end{tabular}

Table 1: Cont.

\begin{tabular}{|l|ccc|ccc|ccc|}
\hline \multirow{2}{*}{ Characters } & \multicolumn{3}{|c|}{$\begin{array}{c}\text { Leaves dry } \\
\text { weight/plant (g) }\end{array}$} & \multicolumn{3}{c|}{$\begin{array}{c}\text { Stem dry weight } \\
\text { (g) }\end{array}$} & \multicolumn{2}{|c|}{ (g) } & \multicolumn{3}{c|}{$\begin{array}{c}\text { Head dry weight } \\
\text { (g) }\end{array}$} \\
\cline { 2 - 9 } & $\mathbf{2 0 0 5}$ & $\mathbf{2 0 0 6}$ & $\mathbf{C o m b}$ & $\mathbf{2 0 0 5}$ & $\mathbf{2 0 0 6}$ & $\mathbf{C o m b}$ & $\mathbf{2 0 0 5}$ & $\mathbf{2 0 0 6}$ & Comb \\
\hline D1 & 33.85 & 35.63 & 34.74 & 65.61 & 73.04 & 69.33 & 93.28 & 99.36 & 96.32 \\
D2 & 31.26 & 32.52 & 31.89 & 64.05 & 66.88 & 65.46 & 86.38 & 90.43 & 88.41 \\
D3 & 28.83 & 29.89 & 29.36 & 57.32 & 59.84 & 58.58 & 74.77 & 79.37 & 77.07 \\
D4 & 23.26 & 24.06 & 23.66 & 51.57 & 53.46 & 52.52 & 56.16 & 59.72 & 57.94 \\
F. Test & $*$ & $*$ & $*$ & $*$ & $*$ & $*$ & $*$ & $*$ & $*$ \\
LSD 5\% & 1.44 & 1.35 & 1.39 & 2.37 & 2.68 & 2.43 & 2.80 & 2.41 & 2.60 \\
\hline
\end{tabular}

\section{2- Effect of plant density on some yield components and quality.}

Table 2 shows the effect of plant density treatments on yield components as well as seed and oil yields of sunflower. Data indicated that there were significant differences among plant density treatments on seed yield per plant as well as seed and oil yields per feddan in the two seasons and its combined plus head diameter trait in 2006 season only. On the other hand, there was no significant difference among plant density treatments on 100 -seed weight and oil percentage plus head diameter trait in 2005 season and combined data of the two seasons. These results were previously reported by Ortegon and Diaz (1997), Naderi (2000) and José et al. (2004). According to the combined data, the first treatment of plant density i.e., 17500 
plants per feddan (D1) with $60 \times 40 \mathrm{~cm}$ space of culture and one plant per hill gave the highest values for all studied yield, yield components and quality characters. This increase my be due to decrease number of plants per hill to single plant and increase space of culture to $60 \times 40 \mathrm{~cm}$ then absent of highly competition between plants.

Table 2: Effect of plant density on some yield components and quality characters of sunflower during 2006 and 2007 seasons and its combined.

\begin{tabular}{|c|c|c|c|c|c|c|c|c|c|}
\hline \multirow{2}{*}{ Characters } & \multicolumn{3}{|c|}{ Head diameter $(\mathrm{cm})$} & \multicolumn{3}{|c|}{ Seed yield/plant $(\mathrm{g})$} & \multicolumn{3}{|c|}{ 100-seed weight (g) } \\
\hline & 2005 & 2006 & Comb & 2005 & 2006 & Comb & 2005 & 2006 & Comb \\
\hline & & & & & & & & & \\
\hline D1 & 15.74 & 1 & 1 & 84.08 & 88.26 & 36.17 & 5.30 & 5.37 & 5.34 \\
\hline D2 & 14.88 & 15. & 15 & 76.55 & 80 & & 5 & 5. & 5. \\
\hline D3 & 13.53 & 14. & 13 & 78.38 & 81.23 & & 4.78 & 6 & 4.82 \\
\hline D4 & 11.99 & 12.19 & 12.09 & 32.74 & 66.76 & 49.75 & 4.40 & 4.48 & 4.44 \\
\hline & * & * & Ns & * & * & 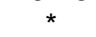 & Ns & Ns & Ns \\
\hline LSD $5 \%$ & -- & 0.56 & -- & 5.29 & 3.20 & 4.10 & -- & -- & -- \\
\hline
\end{tabular}

Table 2:Cont.

\begin{tabular}{|l|ccc|ccc|ccc|}
\hline \multirow{2}{*}{ Characters } & \multicolumn{3}{|c|}{ Seed yield (kg/fed) } & \multicolumn{3}{c|}{ Oil \% } & \multicolumn{3}{c|}{ Oil yield (kg/fed) } \\
\cline { 2 - 10 } & $\mathbf{2 0 0 5}$ & $\mathbf{2 0 0 6}$ & Comb & $\mathbf{2 0 0 5}$ & $\mathbf{2 0 0 6}$ & Comb & $\mathbf{2 0 0 5}$ & $\mathbf{2 0 0 6}$ & Comb \\
\hline Treatments & & & & & & & & & \\
\hline D1 & 1630.11 & 1655.86 & 1642.98 & 34.40 & 35.50 & 34.95 & 559.47 & 586.61 & 573.01 \\
D2 & 1475.36 & 1488.36 & 1481.86 & 33.00 & 33.78 & 33.39 & 485.71 & 501.66 & 493.70 \\
D3 & 1234.09 & 1246.80 & 1240.45 & 32.19 & 33.67 & 32.935 & 396.49 & 419.02 & 407.77 \\
D4 & 1038.07 & 1049.04 & 1043.56 & 30.625 & 31.26 & 30.945 & 317.76 & 327.73 & 322.75 \\
F. Test & $*$ & $*$ & $*$ & Ns & Ns & Ns & $*$ & $*$ & $*$ \\
LSD 5\% & 88.87 & 80.08 & 84.48 & -- & -- & -- & 35.20 & 44.70 & 40.40 \\
\hline
\end{tabular}

\section{2- Varietal differences.}

The date of flowering, vegetative growth, yield attributes, yield and quality of the two sunflower varieties were affected by varietal differences (Tables 3 and 4). The combined data showed that, the cv. Vitoflower (V1) was surpassed over the cv. Earoflower (V2) in all vegetative growth under study i.e. plant height, leaf area, leaves dry weight, stem dry weight and head dry weight concerning the earliest flowering, yield components i.e., seed yield per plant and oil content, while cv. Earoflower had the high score in date of flowering, head diameter, 100-seed weight, seed and oil yields per feddan. From the previous data the $\mathrm{cv}$. Vitoflower produced more vegetative growth than the cv. Earoflower. On the contrary the cv. Earoflower gave the highest seed and oil yields per feddan, where that these results my be due to its higher head diameter and 100-seed weight. These differences between varieties my be due to its genetic structure and the mode of utilization of metabolic products. In this concern, Kabelma (1995), Tobol et al. (1996), Ortegon and Diaz (1997), Ortegon and Diaz (1999), Reddy and Khera (1999), Abelardo and Antonio (2002) and Ibrahim et al. (2006) reported that there are varietal differences between sunflower varieties for vegetative growth, yield and quality characters. 
Table 3: Varieties mean performance for flowering and some vegetative growth characters of sunflower during 2006 and 2007 seasons and its combined.

\begin{tabular}{|c|c|c|c|c|c|c|c|c|c|}
\hline \multirow{2}{*}{$\begin{array}{l}\text { Characters } \\
\text { Varieties }\end{array}$} & \multicolumn{3}{|c|}{$\begin{array}{c}\text { Flowering date } \\
\text { (days) }\end{array}$} & \multicolumn{3}{|c|}{$\begin{array}{c}\text { Plant height } \\
(\mathrm{cm})\end{array}$} & \multicolumn{3}{|c|}{$\begin{array}{c}\text { Leaf area/plant } \\
\left(\mathrm{cm}^{2}\right)\end{array}$} \\
\hline & 05 & & & & & & 005 & & \\
\hline & 52.74 & & & & & & & & \\
\hline 2 & 60.29 & & & 69 & 16 & & 58 & .57 & .07 \\
\hline es & & & & & & & & & \\
\hline
\end{tabular}

Table 3: cont.

\begin{tabular}{|c|c|c|c|c|c|c|c|c|c|}
\hline \multirow{2}{*}{$\begin{array}{l}\text { Characters } \\
\text { Varieties }\end{array}$} & \multicolumn{3}{|c|}{$\begin{array}{c}\text { Leaves dry } \\
\text { weight/plant ( } \mathrm{q} \text { ) }\end{array}$} & \multicolumn{3}{|c|}{ Stem dry weight (g) } & \multicolumn{3}{|c|}{ Head dry weight (g) } \\
\hline & 2005 & 2006 & Comb & 2005 & 2006 & Comb & 2005 & 2006 & Comb \\
\hline V1 & 31.55 & 32.80 & 32.18 & 66.41 & 70.02 & 68.22 & 82.19 & 86.55 & 84.37 \\
\hline $\begin{array}{l}\text { V2 } \\
\text { F. Test }\end{array}$ & $\underset{*}{27.04}$ & $\underset{*}{28.24}$ & $\underset{\star}{27.64}$ & 52.86 & $\underset{*}{56.59}$ & $\underset{*}{54.72}$ & $\underset{*}{73.10}$ & $\underset{*}{77.89}$ & $\underset{*}{75.50}$ \\
\hline
\end{tabular}

Table 4: Varieties mean performance for some yield components and quality characters during 2006 and 2007 seasons and its components.

\begin{tabular}{|c|c|c|c|c|c|c|c|c|c|}
\hline \multirow{2}{*}{$\begin{array}{l}\text { Characters } \\
\text { Varieties }\end{array}$} & \multicolumn{3}{|c|}{ Head diameter $(\mathrm{cm})$} & \multicolumn{3}{|c|}{ Seed yield/plant (g) } & \multicolumn{3}{|c|}{ 100-seed weight (g) } \\
\hline & 2005 & 2006 & Comb & 2005 & 2006 & Comb & 2005 & 2006 & Comb \\
\hline V1 & 13.01 & 13.69 & & 69.23 & 88 & & 4.63 & 4.70 & 4.67 \\
\hline V2 & 15.06 & 15.73 & 15.39 & 66.64 & 69.62 & 68.13 & 5.19 & 5.27 & 5.23 \\
\hline F. Test & & & & & & & & & \\
\hline
\end{tabular}

Table 4: Cont.

\begin{tabular}{|c|c|c|c|c|c|c|c|c|c|}
\hline Characters & Seed & yield $(k$ & g/fed) & & Oil \% & & Oil y & jeld $(\mathrm{kc}$ & $/$ fed) \\
\hline Varieties & 2005 & 2006 & Comb & 2005 & 2006 & Comb & 2005 & 2006 & Comb \\
\hline V1 & 1262.45 & 1275.77 & 1269.12 & 33.50 & 34.58 & 34.04 & 425.51 & 443.55 & 434.54 \\
\hline $\begin{array}{l}\text { V2 } \\
\text { F. Test }\end{array}$ & $\underset{*}{1426.36}$ & 1444.25 & 1435.31 & $\underset{*}{31.60}$ & 32.53 & $\underset{*}{32.07}$ & 454.20 & $\underset{*}{473.96}$ & $\underset{*}{464.08}$ \\
\hline
\end{tabular}

3- Interaction effects.

Effect of the interaction between plant density treatments and the two used sunflower varieties in this study on vegetative growth, yield components, seed and oil yield and quality are shown in Tables 5 and 6 . It is evident that, the two tested sunflower varieties i.e. Vitoflower and Earoflower responded significantly to the differences of plant density treatments. According to the combined data, the interaction between plant density 17500 Plants/fed (D1) when sown in $60 \times 40 \mathrm{~cm}$ space of culture with one plant per hill and Earoflower variety gave the highest values of most of vegetative growth characters i.e., leaves area, leaves dry weight, stem dry weight and head dry weight. On other point of view, the highest values for seed and oil yields per feddan characters were obtained when the sunflower cv. Earoflower and cv. Vitoflower were sown with space of culture $60 \times 40 \mathrm{~cm}$ (17500 plants per feddan). Such results were reported by Ortegon and Diaz (1997) and Reddy and Khera (1999). 
Table 5: Effect of the interaction between plant density and sunflower varieties on flowering and some vegetative growth characters during 2006 and 2007 seasons and its components.

\begin{tabular}{|c|c|c|c|c|c|c|c|c|c|c|}
\hline \multirow{2}{*}{\multicolumn{2}{|c|}{$\begin{array}{l}\text { Characters } \\
\text { Treatments }\end{array}$}} & \multicolumn{3}{|c|}{$\begin{array}{c}\text { Flowering date } \\
\text { (days) }\end{array}$} & \multicolumn{2}{|c|}{ Plant height } & $(\mathrm{cm})$ & \multicolumn{3}{|c|}{ Leaf area/plant $\left(\mathrm{cm}^{2}\right)$} \\
\hline & & 2005 & 2006 & Comb & 2005 & 2006 & Comb & 2005 & 2006 & Comb \\
\hline \multirow[t]{2}{*}{ D1 } & V1 & 54.79 & 52.79 & 53.79 & 200.25 & 198.71 & 199.48 & 890.05 & 935.29 & 912.67 \\
\hline & V2 & 62.38 & 60.38 & 61.38 & 158 & 157 & & 6 & & 79 \\
\hline \multirow[t]{2}{*}{$\mathrm{D} 2$} & V1 & 53.25 & 51.25 & 52. & 20 & 20 & & 0 & & 22 \\
\hline & V2 & 60.75 & 58.75 & 59. & 16 & 15 & 16 & 59 & 62 & 51 \\
\hline \multirow[t]{2}{*}{ D3 } & V1 & 51.54 & 49.54 & 50 & 212 & 21 & & 6 & & 57 \\
\hline & V2 & 59.00 & 57.00 & & 165 & 16 & & 457 & & 86 \\
\hline \multirow[t]{2}{*}{ D4 } & V1 & 51.38 & 50.50 & 50 & 217 & 21 & & 423.22 & & .77 \\
\hline & V2 & 59.04 & 58.13 & 58.59 & 169.33 & 167.08 & 168.21 & 359.76 & 364.50 & 362.13 \\
\hline \multicolumn{11}{|c|}{ LSD at $5 \%$} \\
\hline \multirow{2}{*}{\multicolumn{2}{|c|}{$\begin{array}{l}\text { For D's } \\
\text { For V's }\end{array}$}} & -- & -- & -- & & & 115 & & & 6 \\
\hline & & -- & -- & -- & 1.07 & 0.95 & 1.01 & 66.09 & 55.84 & 60.97 \\
\hline
\end{tabular}

Table 5: Cont.

\begin{tabular}{|c|c|c|c|c|c|c|c|c|c|c|}
\hline \multirow{2}{*}{\multicolumn{2}{|c|}{$\begin{array}{l}\text { Characters } \\
\text { Treatments }\end{array}$}} & \multicolumn{3}{|c|}{$\begin{array}{c}\text { Leaves dry } \\
\text { weight/plant (g) }\end{array}$} & \multicolumn{3}{|c|}{ Stem dry weight (g) } & \multicolumn{3}{|c|}{ Head dry weight (g) } \\
\hline & & 2005 & 2006 & Comb & 2005 & 2006 & Comb & 2005 & 2006 & Comb \\
\hline \multirow[t]{2}{*}{ D1 } & V1 & 37.28 & 38.98 & 38.13 & 74.08 & 80.54 & 77.31 & 102.36 & 108.43 & 105.40 \\
\hline & V2 & 30.41 & 32.27 & 31.34 & 57.13 & 65 & 6 & 0 & 9 & 24 \\
\hline \multirow[t]{2}{*}{ D2 } & V1 & 33.47 & 34.63 & 34.05 & 71.17 & 74.71 & 72.94 & 91.45 & 95.54 & 3.50 \\
\hline & V2 & 29.04 & 30.41 & 29.73 & 56.92 & 59.04 & 57.98 & 81.30 & 85.32 & 3.31 \\
\hline \multirow[t]{2}{*}{ D3 } & V1 & 31.32 & 32.37 & 31.85 & 63.88 & 66.04 & 64.96 & 79.03 & 82.81 & 80.92 \\
\hline & V2 & 26.33 & 27.41 & 26.87 & 50.75 & 53.63 & 52.19 & 70.50 & 75.93 & 73.22 \\
\hline \multirow[t]{2}{*}{ D4 } & V1 & 24.14 & 25.23 & 24.69 & 56.50 & 58.79 & 57.65 & 55.91 & 59.41 & 57.66 \\
\hline & LSD at $5 \%$ & 22.37 & 22.88 & 22.63 & 46.63 & 48.13 & 47.38 & 1 & 03 & .22 \\
\hline \multicolumn{2}{|c|}{$\begin{array}{l}\text { For D's } \\
\text { For V's }\end{array}$} & $\begin{array}{l}0.95 \\
0.41\end{array}$ & $\begin{array}{l}0.56 \\
0.53\end{array}$ & $\begin{array}{l}0.76 \\
0.47\end{array}$ & $\begin{array}{l}0.89 \\
0.82\end{array}$ & $\begin{array}{l}1.37 \\
0.89\end{array}$ & $\begin{array}{l}1.13 \\
0.86\end{array}$ & $\begin{array}{l}1.16 \\
1.18\end{array}$ & $\begin{array}{l}0.90 \\
0.97\end{array}$ & $\begin{array}{l}1.03 \\
1.07\end{array}$ \\
\hline
\end{tabular}

Table 6: Effect of the interaction between plant density and sunflower varieties on some yield components and quality characters during 2006 and 2007 seasons and its components.

\begin{tabular}{|c|c|c|c|c|c|c|c|c|c|c|}
\hline & \multicolumn{3}{|c|}{ Head diameter $(\mathrm{cm})$} & \multicolumn{3}{|c|}{ Seed yield/plant (g) } & \multicolumn{3}{|c|}{ 100-seed weight (g) } \\
\hline & & 2005 & 2006 & Comb & 2005 & 2006 & Comb & 2005 & 2006 & Comb \\
\hline \multirow[t]{2}{*}{ D1 } & V1 & 14.48 & 15.58 & 15.03 & 94.85 & 99.08 & 96.97 & 4.93 & 5.00 & 4.97 \\
\hline & V2 & 17.00 & 18.10 & 17.55 & 73.30 & 77.44 & 75.37 & 5.67 & 5.74 & 5.71 \\
\hline \multirow[t]{2}{*}{$\mathrm{D} 2$} & V1 & 13.69 & 14.49 & 14.09 & 86.57 & 91.47 & 89.02 & 4.79 & 4.84 & 4.82 \\
\hline & v2 & 16.07 & 16.87 & 16.47 & 66.53 & 69.27 & 67.90 & 5.52 & 5.61 & 5.57 \\
\hline \multirow[t]{2}{*}{ D3 } & V1 & 12.51 & 13.11 & 12.81 & 88.43 & 91.82 & 90.13 & 4.53 & 4.61 & 4.57 \\
\hline & V2 & 14.54 & 15.14 & 14.84 & 68.32 & 70.63 & 69.48 & 5.03 & 5.11 & 5.07 \\
\hline \multirow{2}{*}{ D4 } & V1 & 11.36 & 11.56 & 11.46 & 7.07 & 72.39 & 39.73 & 4.27 & 4.35 & 4.31 \\
\hline & LSD at $5 \%$ & 12.61 & 12.81 & 12.71 & 58.40 & 61.12 & 59.76 & 4.53 & 4.60 & 4.57 \\
\hline \multirow{2}{*}{\multicolumn{2}{|c|}{$\begin{array}{l}\text { For D's } \\
\text { For V's }\end{array}$}} & 0.20 & 0.21 & 0.21 & 1.72 & 0.89 & 1.31 & 0.08 & 0.09 & 0.09 \\
\hline & & 0.20 & 0.21 & 0.21 & 2.04 & 1.17 & 1.61 & 0.08 & 0.09 & 0.09 \\
\hline
\end{tabular}


AbdEl-Ghany, H.M. et al.

Table 6: Cont.

\begin{tabular}{|c|c|c|c|c|c|c|c|c|c|c|}
\hline \multirow{2}{*}{\multicolumn{2}{|c|}{$\begin{array}{l}\text { Characters } \\
\text { Treatments }\end{array}$}} & \multicolumn{3}{|c|}{ Seed yield (kg/fed) } & \multicolumn{3}{|c|}{ Oil \% } & \multicolumn{3}{|c|}{ Oil yield $(\mathrm{kg} / \mathrm{fed})$} \\
\hline & & 2005 & 2006 & Comb & 2005 & 2006 & Comb & 2005 & 2006 & Comb \\
\hline \multirow[t]{2}{*}{$\overline{D 1}$} & V1 & 1502.25 & 1517.71 & 1509.98 & 35.34 & 36.38 & 35.86 & 530.90 & 552.14 & 541.48 \\
\hline & V2 & 1757.96 & 1794.00 & 1775.98 & 33.45 & 34.62 & 34.04 & 588.04 & 621.08 & 604.54 \\
\hline \multirow[t]{2}{*}{ D2 } & V1 & 1368.38 & 1382.17 & 1375.28 & 34.01 & 34.82 & 34.42 & 465.39 & 481.27 & 473.37 \\
\hline & V2 & 1582.33 & 1594.54 & 1588.44 & 31.98 & 32.74 & 32.36 & 506.03 & 522.05 & 514.02 \\
\hline \multirow[t]{2}{*}{ D3 } & V1 & 1159.21 & 1171.42 & 1165.32 & 33.21 & 34.70 & 33.96 & 384.97 & 406.48 & 395.74 \\
\hline & V2 & 1308.96 & 1322.17 & 1315.57 & 31.17 & 32.64 & 31.91 & 408.00 & 431.56 & 419.80 \\
\hline \multirow[t]{2}{*}{ D4 } & V1 & 1019.96 & 1031.79 & 1025.88 & 31.45 & 32.40 & 31.93 & 320.78 & 334.30 & 327.56 \\
\hline & V2 & 1056.17 & 1066.29 & 1061.23 & 29.80 & 30.12 & 29.96 & 314.74 & 321.17 & 317.94 \\
\hline \multicolumn{11}{|c|}{ LSD at $5 \%$} \\
\hline \multicolumn{2}{|c|}{ For D's } & 30.74 & 34.42 & 32.58 & 2.10 & 2.00 & 2.50 & 38.70 & 49.89 & 44.75 \\
\hline \multicolumn{2}{|c|}{ For V's } & 28.76 & 27.42 & 28.09 & 2.05 & 1.99 & 2.00 & 29.20 & 32.60 & 31.40 \\
\hline
\end{tabular}

With regard to plant density, it seems that the optimum plant population for the achievement of maximum yields of sunflower under the conditions of this study lies between 17500 plants/fed (D1) with $60 \times 40 \mathrm{~cm}$ space of culture and 3500 plants/fed (D2) with $60 \times 20 \mathrm{~cm}$ space of culture. The lower densities do not produce a sufficient number of seeds per unit area, while the higher ones reduce both the number of seed and seed weight. However, the relatively small absolute differences in seed yield between plant densities demonstrate the remarkable compensation capacity of sunflower between the different yield components.

\section{REFERENCES}

A.O.A.C. (1984). "Official Methods of Analysis of the Association of Official Analytical Chemists"13rd ed., Washington, D.C.

Abelardo J. de la Vega and J. Antonio (2002). Hall effects of planting date, genotype, and their interactions on sunflower yield: II. Components of oil yield. Crop. Sci., 42:1202-1210.

Allam, A.Y. and, A.H. Galal. (1996). Effect of nitrogen fertilization and plant density on yield and quality of sunflower. Assiut J. of Agric. Sci., 27 (2): 169-177.

Andrade, F.H. (1995). Analysis of growth and yield of maize, sunflower and soybean grown at Balcarce, Argentina. Field Crops Res., 41: 1-12.

Beard, B.H. and, S. Geng (1982). Interrelationships of morphological and economic characters of sunflower. Crop Sci., 22:817-822.

Diepenbrock, W.; M. Long and B. Feil (2001). Yield and quality of sunflower as affected by row orientation, row spacing and plant density. Aust. J. Agric. Res., 52: 29-36. 
Ibrahim, M.E.; H.M. Abd El-Ghany and N.A. Gaafar. (2006). Effect of nitrogen fertilizer and its application time on growth and yield of two sunflower varieties. Bull. NRC, Egypt, 31: 233 -243.

José, F.C. Barros; Mário de Carvalho and Gottlieb Basch (2004). Response of sunflower (Helianthus annuus, L.) to sowing date and plant density under Mediterranean conditions. Eur. J. Agron., 21 (3): 347-356

Kabelma, B. (1995). Effect of row spacing on yield of two sunflower cultivars. Al-Awamia, 91: 41-47.

Naderi, A. (2000). Effect of row spacing and plant population on agronomic traits, yield and yield components of sunflower cultivar record in Khuzestan. Seed and Plant, 15 (4): 343-353.

Ortegon, A.S. and F.A. Diaz (1997). Productivity of sunflower cultivars in relation to plant density and growing season in Northern Tamaulipas, Mexico. Helia, 20 (26): 113-119.

Ortegon, A.S. and F.A. Diaz (1999). Response of sunflower cultivars to plant density under two conditions. Agronomia Mesoamericana, 10 (2): 1721.

Putt, E.D. (1977). Early history of sunflower. p. 1-19. in A.A. Schneiter (ed.) Sunflower technology and production. ASA, CSSA, and SSSA. Madison, WI.

Reddy, D.D. and M.S. Khera (1999). Fertilizer, plant density and variety interactions and soil nutrient status under maximum yield research on maize-sunflower system. Inter. J. of Tropical Agric., 17: 1-4.

Sarmah, P.C.; S.K. Katyal and M.C. Debnath (2000). Effect of fertility levels and plant populations on some physiological parameters of sunflower. Crop Res. Hisar, 19 (3): 391-397.

Snedecor, G.M. and W.G. Cochran (1980). Statistical Methods. 7th ed., lowa State Univ. USA.

Tanzi, F.; C. Cornia and T. (Maggiore 1997). Plant density for sunflowers. Informatore Agrario Supplemento, 53 (9): 31-33.

Tenebe, V.A.; U.R. Pal; C.A. Okonokwo and B.M. Auwalu (1996). Response of rainfed sunflower (Helianthus annuus, L.) to nitrogen rates and plant population in the semi-arid savanna region of Nigeria. J. of Agron. and Crop Sci., 177 (3): 207-215.

Tobol, P.; C. Musnicki; and B. Musnicka (1996). Response of two oilseed sunflower varieties with different genotype to nitrogen fertilizer application. Rosliny Oleiste, 17 (2): 423-428.

Villalobos, F.J.; V.O. Sadras; A. Soriano and E. Fereres (1994). Planting density effects on dry matter partitioning and productivity of sunflower hybrids. Field Crops Res., 36 (1): 1-11. 


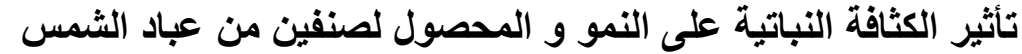

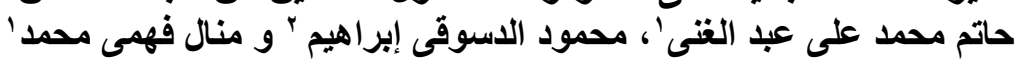

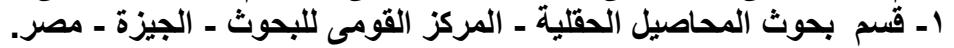

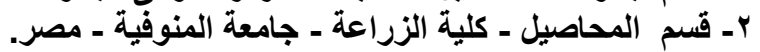

أجرى هذا البحث بمزرعة كلية الزراعة - جامعة المنوفية بشبين الكوم خلال موسمي

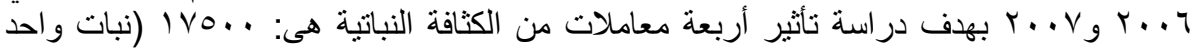

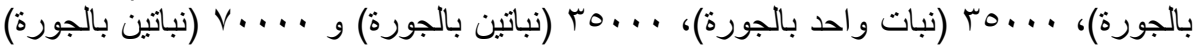

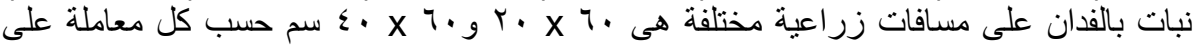

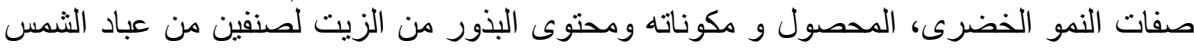

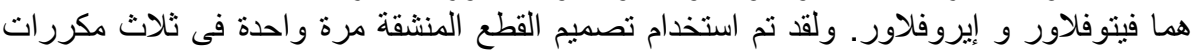

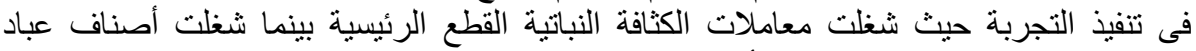

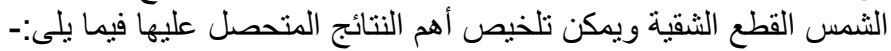

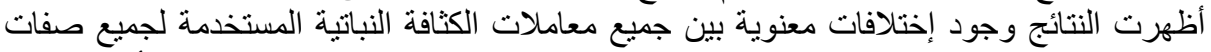

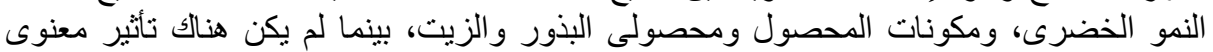

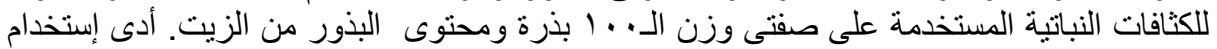

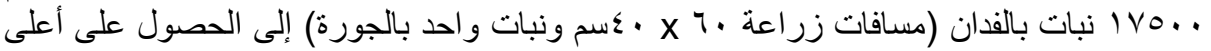

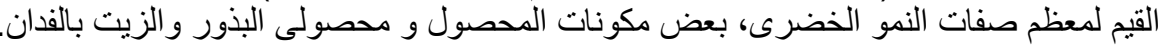

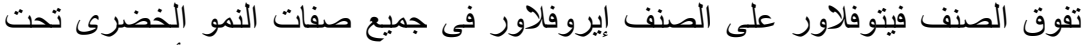

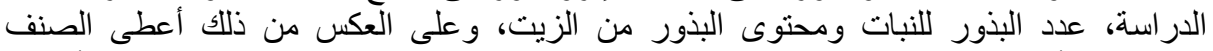

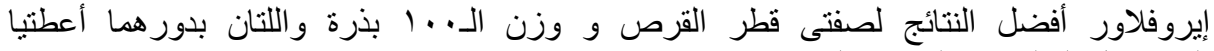

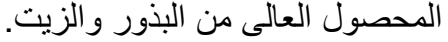

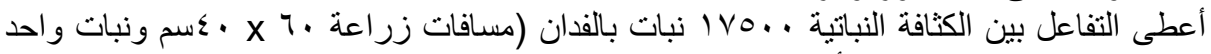

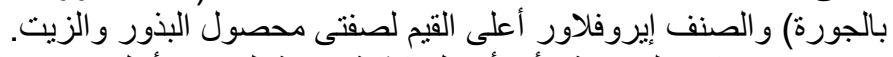

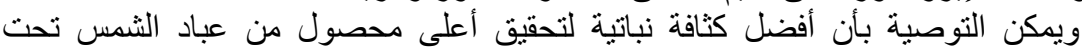

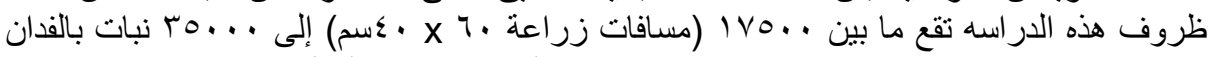

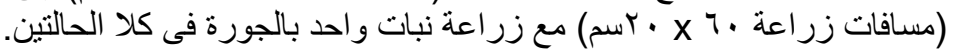


J. Agric. Sci. Mansoura Univ., 33 (3), March, 2008

1761

1762

1763

1764

1765

1766

1767

1768

1769

1770 